\title{
Prevalence of Symptomless Urinary Tract Disease in Birmingham Schoolchildren. I-Pyuria and Bacteriuria
}

\author{
S. ROY MEADOW,* M.R.C.P., D.C.H., D.oBST.R.C.o.G.; RICHARD H. R. WHITE,† M.B.; M.R.C.P., D.C.H. \\ NATALIE M. JOHNSTON, L.R.C.P.\&S.ED., D.P.H. \\ With THE TECHNICAL hELP OF ANDREW J. F. BROWNING $\S$
}

British Medical fournal, 1969, 3, 81-84

\begin{abstract}
Cummary : In a pilot project 2,122 schoolchildren were screened for symptomless urinary tract disease by the examination of midstream urine specimens. These were tested for albumin, blood, and glucose with Labstix commercial strips, together with microscopy for abnormal cellular excretion.
\end{abstract}

One case of renal glycosuria was found but none of previously undiagnosed diabetes mellitus. Out of 1,096 boys, $11(1 \%)$ had pyuria-a leucocyte count greater than $10 /$ cu.mm. - but only four showed abnormal counts on retesting. None had urinary tract infection.

Out of 1,026 girls, $96(9.3 \%)$ had pyuria initially but 35 were normal on retesting. Of the remaining 61 girls, 59 attended the outpatients department for further investigation, and in 30 vulvitis appeared to be the sole cause. Ten were proved to have significant bacteriuria and six of them showed radiological abnormalities.

It is suggested that careful long-term studies are needed to study the economics and the implications of screening on a national scale.

\section{Introduction}

From the careful studies of Hodson and Wilson (1965) it is evident that most examples of chronic pyelonephritis in young adults originate in childhood. Kunin et al. (1964) found a $1.2 \%$ prevalence of asymptomatic bacteriuria in North American schoolgirls. They urged that other communities should adopt screening programmes, believing that the incidence of irreversible pyelonephritis in young women could be reduced as a result. We therefore decided to undertake a pilot project among Birmingham schoolchildren. It was designed with the twofold objective of estimating the prevalence of symptomless urinary tract disease, notably infection, and of assessing the feasibility of including urine examination in the routine school medical inspection. In this paper we give a brief description of the project and report in detail the results of screening for evidence of urinary tract infection.

\section{Material and Methods}

The survey was carried out between October 1967 and January 1969 at a school situated in a south-western suburb of Birmingham. The school campus contains infants', junior, secondary boys', and secondary girls' sections in adjacent buildings. Most of the 2,125 pupils ( 1,097 boys and 1,028

\footnotetext{
* Lately Senior Research Fellow, Institute of Child Health, Birmingham 16. Present address: Department of Paediatrics, Guy's Hospital, London S.E.1.

† Senior Lecturer and First Assistant in Paediatrics and Child Health, Birmingham University; Honorary Consultant Paediatrician, United Birmingham Hospitals.

$\ddagger$ Senior School Medical Officer, City of Birmingham.

$\$$ Medical Student, Birmingham University.
}

girls) inhabit modern council houses, and their fathers are predominantly semiskilled employees in light engineering or the motor-car industry. There is no coloured immigrant population in the locality, though the junior school contained two fostered Negro children at the time of the study. In seeking the co-operation of the staff and pupils an undertaking was given that treatment would be offered at the Birmingham Children's Hospital for any case of urinary tract disease disclosed, by arrangement with the parents and general practitioner.

The initial screening procedure consisted of examining a single voided urine sample from each pupil. Each child was provided with an unsterilized 50-ml. plastic-capped container, together with printed instructions on the collection of a midstream urine specimen. Girls were asked to wash and dry their genitalia, using soap and water, before passing urine directly into the container ; senior girls were requested not to make the collection during menstruation. Boys were instructed to pass midstream specimens, withdrawing the prepuce if possible. The urine was collected at home before the journey to school, and in most cases represented the first morning specimen. Containers were handed in on arrival at school and conveyed to the Children's Hospital without delay.

Each specimen was tested for $p \mathrm{H}$ and for the presence of albumin, blood, and glucose, Labstix commercial strips being used. Formed elements in the urine were examined microscopically by means of a four-chamber modified FuchsRosenthal crystalite counting chamber of $0.1 \mathrm{~mm}$. depth. The red and white blood cells contained in $0.9 \mathrm{cu}$. $\mathrm{mm}$. of wellmixed uncentrifuged urine from each sample were counted. The work of urine analysis was shared between three of us (S. R. M., R. H.R.W., and A. J.F. B.) ; cell counts were carried out in triplicate on the first batch of 50 specimens, however, and showed close agreement.

A urine specimen was considered abnormal if it gave an albumin reading of one-plus or more, a positive occult blood or glucose test, or contained erythrocytes or more than 10 leucocytes per cu. mm. A child whose initial urine specimen showed any of these abnormalities was asked to produce a further specimen the following week. If the abnormality persisted the child was seen by appointment in the renal clinic at the Children's Hospital three or four days later. In the case of an initial leucocyte count of more than $50 / \mathrm{cu}$. mm., however, the child was asked to attend the clinic without supplying a second specimen, in view of the greater likelihood that urinary tract infection was the cause.

All children attending the clinic were given a full clinical examination, including inspection of the genitalia. Midstream urine specimens were then obtained ; in the case of girls vaginal swabs were taken before the genitalia were cleansed. Urine specimens were inoculated on to MacConkey and blood agar plates, bacterial colony counts being carried out in every case. Bacteriuria was considered significant when not fewer than two consecutive specimens taken on separate days contained the same pathogen in pure culture at a concentration of more than 
$100,000 / \mathrm{ml}$. In certain cases suprapubic aspiration was performed in order to obtain an uncontaminated specimen.

\section{Results}

There was excellent participation. Only three of the 2,125 children did not produce an initial specimen, and only three of those requested to provide a second specimen failed to comply. The attitudes of the school staff and parents undoubtedly contributed to the success of the project. We were impressed by the "cleanliness" of most urine specimens, which reflected the ability of the parents and their children to follow our instructions.

The results of investigations on patients with persistent proteinuria or microscopical haematuria will be published in detail separately but are briefly summarized here.

\section{Proteinuria}

One-plus Albustix readings were often recorded in initial specimens, but only $17(0.8 \%)$ children had readings of one plus or more on two consecutive weekly tests. Significant proteinuria persisted longer than one month in five children, of whom two were found to have postural proteinuria, one showed "minimal changes" on renal biopsy, one probably had poststreptococcal glomerulonephritis, and one was a known case of membranoproliferative glomerulonephritis (Ogg et al., 1968) receiving treatment elsewhere. None had urinary tract infection.

\section{Haematuria}

Eight children had microscopical haematuria on two consecutive weekly tests. Further investigation showed two children with probable poststreptococcal glomerulonephritis and four with minimal glomerular abnormalities on renal biopsy. None had urinary tract infection.

\section{Glycosuria}

Four boys gave positive tests for glucose, but one was negative on retesting. It was subsequently found that one of the remaining three was a diabetic receiving treatment and another ivas having steroid therapy for membranoproliferative glomerulonephritis. On further investigation the third boy proved to have renal glycosuria.

\section{Pyuria : Boys}

Of the 1,096 boys who participated, 1,085 (99\%) had urinary leucocyte counts of less than $10 / \mathrm{cu} . \mathrm{mm}$.; indeed, $95 \%$ of counts were less than $5 / \mathrm{cu}$. mm. and most of the $0.9-\mathrm{ml}$. samples examined contained no cells at all. Initial specimens from 11 boys (1\%) gave leucocyte counts greater than 10/cu. $\mathrm{mm}$., but only four showed persistent abnormalities when retested a week later. Two of them had balanitis, one probably had poststreptococcal glomerulonephritis, and the fourth, who also had heavy proteinuria, was known to have membranoproliferative glomerulonephritis. None was found to have urinary tract infection. In urine specimens obtained from several adolescent boys we observed large numbers of round cells, which superficially resembled leucocytes but appeared hyaline rather than granular when examined under a $1 / 6$ objective. They were always associated with the presence of spermatozoa, and with the aid of Millipore preparations (S. R. Meadow, unpublished) we were able to discern that in fact they were the swollen hydropic heads of degenerate spermatozoa whose tails had already separated.

\section{Pyuria : Girls}

Table I shows the prevalence of pyuria in 1,026 girls who initially supplied urine samples. The results are analysed in terms of age groups corresponding to the school sections. A total of $96(9.3 \%)$ had pyuria, which we defined as a urinary leucocyte count greater than $10 / \mathrm{cu}$. $\mathrm{mm}$. It is noteworthy that the proportion of 5-7-year-old girls yielding abnormal counts was much higher than that of girls aged 8 years or more. Of the 54 girls giving specimens with leucocyte counts of $11-50 / \mathrm{cu}$. mm. only 19 showed persistent abnormalities on retesting. These 19 , together with 42 girls whose initial leucocyte counts were greater than $50 / \mathrm{cu}$. mm., were requested to attend the renal clinic for further investigation; two failed to keep their appointments. Two of the 59 who attended also had transient proteinuria for which no cause was found. A further three girls who had raised leucocyte counts in their initial urine samples attended the clinic primarily for investigation of persistent proteinuria, and another because of microscopical haematuria; they will be discussed in a separate publication.

TABL I-Prevalence of Pyruria in Single Midstream Urine Samples Collected at Home by 1,026 Schoolgirls Aged 5-16 Years

\begin{tabular}{|c|c|c|c|c|c|c|c|c|c|c|c|}
\hline \multirow{3}{*}{$\begin{array}{c}\text { Age } \\
\text { Range } \\
\text { (Years) }\end{array}$} & \multirow{3}{*}{$\begin{array}{l}\text { Total } \\
\text { Screened }\end{array}$} & \multirow{2}{*}{\multicolumn{2}{|c|}{$\begin{array}{c}\text { Total } \\
\text { with } \\
\text { Pyuria* }\end{array}$}} & \multicolumn{8}{|c|}{$\begin{array}{c}\text { No. with Leucocyte Counts (/cu.mm.) } \\
\text { as follows: }\end{array}$} \\
\hline & & & & \multicolumn{2}{|c|}{$11-50$} & \multicolumn{2}{|c|}{$51-100$} & \multicolumn{2}{|c|}{$101-1,000$} & \multicolumn{2}{|c|}{$>1,000$} \\
\hline & & No. & $\%$ & No. & $\%$ & No. & $\%$ & No. & $\%$ & No. & $\%$ \\
\hline $\begin{array}{c}5-7 \\
8-10 \\
11-16\end{array}$ & $\begin{array}{l}178 \\
213 \\
635\end{array}$ & $\begin{array}{l}35 \\
18 \\
43\end{array}$ & $\begin{array}{r}19 \cdot 4 \\
8.4 \\
6.8\end{array}$ & $\begin{array}{r}25 \\
7 \\
22\end{array}$ & $\begin{array}{r}13.9 \\
3.3 \\
3.5\end{array}$ & $\begin{array}{r}4 \\
5 \\
14\end{array}$ & $\begin{array}{l}2 \cdot 2 \\
2 \cdot 3 \\
2 \cdot 2\end{array}$ & $\begin{array}{l}6 \\
4 \\
5\end{array}$ & $\begin{array}{l}3.3 \\
1.9 \\
0.8\end{array}$ & $\begin{array}{l}0 \\
2 \\
2\end{array}$ & $\begin{array}{l}0.9 \\
0.3\end{array}$ \\
\hline $5-16$ & 1,026 & 96 & $9 \cdot 3$ & 54 & $5 \cdot 2$ & 23 & $2 \cdot 2$ & 15 & 1.5 & 4 & 0.4 \\
\hline
\end{tabular}

- Pyuria is defined as a leucocyte count exceeding 10/cu.mm.

The final diagnosis in 59 girls who were investigated primarily on account of pyuria are shown in Table II. On clinical examination 33 were found to have vulvitis. Three of them also had urinary tract infection, but vulvitis was presumed to be the sole cause of pyuria in the remaining 30 . In most cases a history of soreness or discharge, or both, was obtained, though of ten unrecognized by the girls' mothers. In prepubertal girls, in whom the incidence of vulvitis was striking, erythema of the vestibule was generally prominent and discharge minimal, whereas in adolescent girls purulent vaginal discharge usually overshadowed the inflammation. Vaginal swabs grew organisms known to cause vulvovaginitis in 11 patients; they included Streptococcus pyogenes (3), pneumococcus (2), Haemophilus influenzae (1), Staphlylococcus pyogenes (1), and, in older girls, Candida albicans (2) and Trichomonas vaginalis (2). Seven adolescent girls were found to have leucorrhoea, which is an excessive physiological vaginal discharge consisting of mucus, squamous epithelial cells, and leucocytes. In the remaining 19 girls no abnormality was found on clinical examination, but investigations showed that six of them had urinary tract infection. Thus pyuria was unexplained in three girls, but in every case at least one "clean-catch" urine specimen obtained in the clinic had a normal leucocyte count.

TABLE II.-Final Diagnoses in 59 Girls Who Attended the Outpatient Department for Investigation of Pyurio

\begin{tabular}{|c|c|c|c|c|c|c|c|c|}
\hline \multirow{3}{*}{$\begin{array}{c}\text { Age } \\
\text { Range } \\
\text { (Years) }\end{array}$} & \multicolumn{8}{|c|}{ Number of Girls } \\
\hline & \multirow{2}{*}{$\begin{array}{c}\text { Total } \\
\text { Screened }\end{array}$} & \multicolumn{2}{|c|}{$\begin{array}{l}\text { Attended } \\
\text { Clinic }\end{array}$} & \multicolumn{2}{|c|}{$\begin{array}{c}\text { Urinary } \\
\text { Infection* }\end{array}$} & \multirow{2}{*}{$\begin{array}{l}\text { Vul- } \\
\text { vitis* }\end{array}$} & \multirow{2}{*}{$\begin{array}{l}\text { Leucor- } \\
\text { rhoea }\end{array}$} & \multirow{2}{*}{$\begin{array}{c}\text { No Abnor } \\
\text { mality }\end{array}$} \\
\hline & & No. & $\%$ & No. & $\%$ & & & \\
\hline $\begin{array}{c}5-7 \\
8-10 \\
11-16\end{array}$ & $\begin{array}{l}178 \\
213 \\
635\end{array}$ & $\begin{array}{l}19 \\
11 \\
29\end{array}$ & $\begin{array}{r}10 \cdot 7 \\
5.2 \\
4.7\end{array}$ & $\begin{array}{l}3 \\
2 \\
4\end{array}$ & $\begin{array}{l}1.7 \\
0.95 \\
0.6\end{array}$ & $\begin{array}{r}8 \\
10 \\
15\end{array}$ & $\overline{7}$ & $\begin{array}{l}7 \\
1 \\
5\end{array}$ \\
\hline Total & 1,026 & 59 & $5 \cdot 8$ & 9 & 0.9 & 33 & 7 & 13 \\
\hline
\end{tabular}

- Three girls (one in each age group) had both vulvitis and urinary infection. 


\section{Bacteriuria}

Nine of the 59 girls referred to the renal clinic on account of pyuria were found to have significant bacteriuria and were diagnosed as having urinary tract infection (Table II). In all but one we recorded the presence of large numbers of nonmotile bacteria in the urine, as well as leucocytes. At the beginning of the project we had not anticipated the value of looking for bacteria in wet preparations, but, like Kunin (1961), we came to appreciate its significance as the study proceeded. As a result two girls whose urine specimens gave normal leucocyte counts but contained masses of bacteria were further investigated, and significant bacteriuria was confirmed in one of them.

Thus 10 girls $(1 \%)$ were proved to have bacteriuria. Their clinical, bacteriological, and radiological findings are detailed in Table III. On inquiry all except one child gave a history of symptoms which in three instances suggested that they had had a recent attack of acute pyelonephritis. Six were persisent bed-wetters. It is noteworthy that in four patients we obtained at least one normal leucocyte count before starting treatment, and that none had significant proteinuria. In each case the infecting organism was cultured from at least two "clean-catch" urine specimens in a concentration of more than 100,000 bacteria per ml., and in most instances the colony count was more than 25 million per ml. of urine. In six girls (including the three with vulvitis) suprapubic aspiration confirmed the origin of the bacteria; in two of the remaining four it was carried out when they relapsed after treatment. Intravenous urography and micturating cystourethrography were carried out in all 10 patients, revealing abnormalities in six. One girl was found to have a right pelviureteric obstruction, which has since been corrected surgically. All 10 responded to initial treatment, but five relapsed within five months of starting treatment. Long-term supervision and therapy, where indicated, are continuing.

\section{Discussion}

Undoubtedly the most important result of this pilot survey was the detection of 10 cases of urinary tract infection among 1,026 schoolgirls. This prevalence is slightly below the $1 \cdot 2 \%$ rate which Kunin et al. (1964) found in American schoolgirls. However, they used bacterial colony counts as their initial screening procedure. More instances of significant bacteriuria might have been detected in Birmingham had we used a similar method, since not all urinary infections are associated with continuous pyuria, as Table III shows. No instance of urinary tract infection was found among 1,096 boys screened. This is in keeping with the $0.04 \%$ prevalence of bacteriuria which Kunin et al. (1962) found in schoolboys, and it therefore appears that screening boys for urinary tract infection is comparatively unrewarding, regardless of the method used.

Our screening methods were comparatively rapid and simple ; 50 specimens could be examined by two trained persons in about one hour. A great deal of time, however, was occupied by administration of the scheme and further investigation of abnormalities detected. Unfortunately our upper limit of normal urinary leucocyte concentration $(10 / \mathrm{cu}$. mm.) yielded an unacceptably high rate of false positives, with the result that 59 girls with pyuria $(5.8 \%)$ had to be seen in the hospital outpatient department in order that a diagnosis of urinary tract infection could be established in nine of them. Moreover, one bacteriuric girl had an initial urinary leucocyte count of only $4 / \mathrm{cu}$. mm. Had we raised our limit to 50 leucocytes per cu. mm. there still would have been 39 girls to investigate while three with infection, all of whom had radiological abnormalities, would have escaped detection. The commonest single cause of pyuria was vulvitis, affecting mostly prepubertal girls ; in these a diagnosis of urinary tract infection could be confidently eliminated only by quantitative urine culture.

Thus screening by a bacteriological method has the definite advantage that it detects bacteriuria unaccompanied by pyuria while yielding a much lower rate of false positives. Quantitative bacteriology is too costly and elaborate for population screening on a large scale, and at present the alternative is a semiquantitative technique such as the blotting-paper strip (Leigh and Williams, 1964), dip-spoon (Mackey and Sandys, 1965), or dip-slide (Guttmann and Naylor, 1967). More promising, though not yet completely validated, is the method which detects the reduction of normal urinary glucose levels resulting from bacterial consumption (Scherstén and Fritz, 1967).

The remarkable participation of over $99.8 \%$ of pupils at the school we screened shows that where good relations exist between the school staff, parents, pupils, and the school health service, schoolchildren provide an ideal captive population for the practice of worth-while preventive medicine. It is, however, doubtful whether screening only once is sufficient, for Kunin et al. (1964) reported that $0.7 \%$ of schoolgirls whose urine specimens were initially normal had developed significant bacteriuria when retested two years later. The optimum age for screening is also debatable. The figures in Table II suggest a declining prevalence of bacteriuria with increasing age, in keeping with the findings of Kunin et al. (1964). It is likely that many instances of irreversible pyelonephritic scarring arise before school entry at the age of 5 years. Most neonatal urinary tract infections appear to be self-limiting and are thus unlikely to make an important contribution to the incidence of chronic pyelonephritis, according to the evidence accumulated by MacGregor and Freeman (1968). Accordingly they suggested screening children who attend infant welfare clinics, but unfortunately these represent only $47 \%$ of the total population under 5 years old (Central Health Services Council, 1968). Moreover, it is exceedingly difficult to obtain uncontaminated urine specimens from children of this age, especially when disposable collecting bags are used (Newman et al., 1967 ; O'Doherty, 1968), and screening by quantitative or even semiquantitative bacteriology would therefore be impracticable.

In order to justify the establishment of a national screening programme, either before or after the age of 5 years, there

TABLE III.-Clinical, Urinary, and Radiological Findings in 10 Girls who were Found to have Bacteriuria

\begin{tabular}{|c|c|c|c|c|c|c|c|}
\hline \multirow{2}{*}{$\begin{array}{l}\text { Age } \\
\text { (Yeats, } \\
\text { Months) }\end{array}$} & \multirow{2}{*}{ Clinical Findings } & \multicolumn{3}{|c|}{ First Urine Sample: } & \multirow{2}{*}{$\begin{array}{c}\text { Subsequent } \\
\text { Samples: } \\
\text { w.B.C./cu.mm. }\end{array}$} & \multirow{2}{*}{$\begin{array}{c}\text { Urinary } \\
\text { Pathogen }\end{array}$} & \multirow{2}{*}{ Radiological Abnormalities } \\
\hline & & Albustix & W.B.C./cu.mm. & Bacteria Visible & & & \\
\hline $\begin{array}{r}5.0 \\
5.1 \\
7 \cdot 6\end{array}$ & $\begin{array}{l}\text { Vulvitis } \\
\text { Enuresis, frequency } \\
\text { Enuresis }\end{array}$ & $\begin{array}{c}0 \\
0 \\
\text { Trace }\end{array}$ & $\begin{array}{l}110 \\
260 \\
220\end{array}$ & $\begin{array}{l}+ \\
+ \\
+\end{array}$ & $\begin{array}{l}17,6 \\
63,280 \\
100,240\end{array}$ & $\begin{array}{l}\text { E. coli } \\
\text { E. coli } \\
\text { Klebsiella }\end{array}$ & $\begin{array}{l}\text { None } \\
\text { Bilateral vesicoureteric reflux } \\
\text { None }\end{array}$ \\
\hline $\begin{array}{l}10.10 \\
11 \cdot 3\end{array}$ & $\begin{array}{l}\text { Enuresis; recent loin pain and } \\
\text { fever; vulvitis } \\
\text { Enuresis until recently }\end{array}$ & $\begin{array}{l}0 \\
0\end{array}$ & $\begin{array}{l}1,100 \\
200\end{array}$ & $\stackrel{+}{\text { Unrecorded }^{+}}$ & $\begin{array}{c}44,39 \\
400,190\end{array}$ & $\begin{array}{l}\text { Klebsiella } \\
\text { E. coli }\end{array}$ & $\begin{array}{l}\text { None } \\
\text { Occult spina bifida; trabeculated bladder }\end{array}$ \\
\hline $\begin{array}{l}11 \cdot 4 \\
12 \cdot 2 \\
12 \cdot 11\end{array}$ & $\begin{array}{l}\text { Enuresis 3-8 years } \\
\text { Bilateral loin pain recently } \\
\text { Enuresis and dysuria; vulvitis }\end{array}$ & $\begin{array}{l}\text { Trace } \\
\text { Trace } \\
0\end{array}$ & $\begin{array}{r}4 \\
105 \\
94\end{array}$ & $\begin{array}{l}+ \\
+ \\
+\end{array}$ & $\begin{array}{r}0,18 \\
6,2 \\
81,47\end{array}$ & $\begin{array}{l}\text { E. coli } \\
\text { E. coli } \\
\text { E. coli }\end{array}$ & $\begin{array}{l}\text { Wilateral vesicoureteric reflux } \\
\text { Right pelviureteric obstruction } \\
\text { Oocult spina bifida; trabeculated bladder } \\
\text { with large capacity and two diverticula }\end{array}$ \\
\hline $\begin{array}{l}15 \cdot 1 \\
16 \cdot 3\end{array}$ & $\begin{array}{l}\text { Frequency and dysuria } 3 \text { months } \\
\text { previously } \\
\text { No abnormality }\end{array}$ & $\stackrel{0}{0}$ & $\begin{array}{r}2,180 \\
17\end{array}$ & $\stackrel{+}{+}$ & $\begin{array}{r}55,26 \\
22,0\end{array}$ & $\begin{array}{l}\text { E. coli } \\
\text { E. coli }\end{array}$ & $\begin{array}{l}\text { None } \\
\text { Slightly distorted right superior calix } \\
\text { without cortical loss }\end{array}$ \\
\hline
\end{tabular}


must be reasonable certainty that most of the bacteriuric children detected will be helped by treatment. Little is known about the long-term effects of symptomless bacteriuria in children (as opposed to recurrent symptomatic infections), and this problem deserves further study. Nevertheless, radiological investigations carried out in our 10 patients with bacteriuria showed two girls with vesicoureteric reflux, which is often associated with the development of pyelonephritic scarring (Smellie and Normand, 1968), one case of pelviureteric obstruction which proved amenable to treatment by a curative surgical operation, and two instances of probable neurological defect of the bladder neck for which long-term medical supervision is necessary.

Kunin et al. (1964) reported symptoms referable to the lower urinary tract in $39 \%$ of the bacteriuric girls whom they interviewed. All but one of the 10 Birmingham girls with bacteriuria had a variety of symptoms which either they, or their parents, or their physicians had considered trivial; three gave histories suggesting previous attacks of acute pyelonephritis but none had had her urine cultured. We have seen in our clinic a number of children who have been treated intermittently for recurrent urinary tract infections and yet have had neither radiological investigations nor regular examination of the urine. Some have been found to have permanent renal damage. Patients have also been referred with a diagnosis of urinary tract infection on account of positive Albustix readings. Moreover, this diagnosis has to our knowledge been ruled out when the Albustix test has been negative ; it should be emphasized that none of the 10 bacteriuric girls in this series was found to have significant proteinuria. Thus it might seem that priority should be given to education concerning the natural history, diagnosis, and management of urinary tract infection in children, and to the provision of adequate diagnostic facilities for all doctors. This would take a long time to achieve, however, and because screening for bacteriuria has such an enormous potential for the prevention of ill-health we believe that continued efforts should be directed towards making it feasible on a national scale. It is therefore pertinent to make at least a cursory examination of the economics.

With the methods that we employed in this pilot survey a single screening of the 90,000 schoolgirls in Birmingham would be expected to yield some 5,200 paediatric outpatient attendants, of whom no fewer than 4,300 would be "falsepositives." This unmanageable load could be substantially reduced by screening for bacteriuria rather than pyuria, but any of the available bacteriological methods would demand the collection of clean-catch specimens at school by trained nurses, as well as mobile laboratory or refrigeration facilities. The advantage of the chemical method described by Scherstén and Fritz (1967), from which they have developed a paper-strip test (Scherstén et al., 1968) is that early-morning specimens could be obtained at home without special precautions provided that bacterial contaminants could be reliably inhibited. This method is being explored.
Finally, more than 900 girls with bacteriuria would be found by city-wide screening. Would they all require radiological invéstigations, treatment, and follow-up ? And, indeed, do we possess the necessary resources? These questions can be answered only by careful long-term study. At the present time we would therefore hesitate to recommend the adoption of screening on a national scale. Instead we would urge the establishment of further research projects, which should concentrate on the development of simpler and cheaper methods and on evaluation of the clinical significance of "symptomless" bacteriuria, but which could nevertheless be presented to individual communities in the form of health programmes, as in our pilot study.

We wish to thank the Special Services Subcommittee of Birmingham City Council and Dr. E. L. M. Millar, Medical Officer of Health, for permission to conduct this survey at Turves Green School, Northfield ; Dr. M. E. Lemin, lately senior school medical officer, for his encouragement, and his clerical staff for their assistance; Dr. K. B. Rogers, consultant microbiologist, and his staff at the Children's Hospital, for performing numerous bacteriological investigations; and Messrs. Ames Company for kindly supplying Labstix test-strips. The project could not have been carried out without the willing co-operation of the school staff, pupils, parents, and local general practitioners, to all of whom we are grateful. S.R.M. was in receipt of a Medical Research Grant from October 1967 to September 1968. A. J. F. B. participated in the study during his weekly elective study periods.

\section{REFERENCES}

Central Health Services Council (1968). Child Welfare Centres. London, H.M.S.O.

Guttmann, D., and Naylor, G. R. E. (1967). British Medical fournal, 3, 343.

Hodson, C. J., and Wilson, S. (1965). British Medical fournal, 2, 191. Kunin, C. M. (1961). New England Fournal of Medicine, 265, 589.

Kunin, C. M., Deutscher, R., and Paquin, A., jun. (1964). Medicine, 43, 91 .

Kunin, C. M., Zacha, E., and Paquin, A. J., jun. (1962). New England Fournal of Medicine, 266, 1287.

Leigh, D. A., and Williams, J. D. (1964). Fournal of Clinical Pathology, $17,498$.

MacGregor, M., and Freeman, P. (1968). In Urinary Tract Infection, edited by F. O'Grady and W. Brumfitt, p. 95. London, Oxford University Press.

Mackey, J. P., and Sandys, G. H. (1965). British Medical fournal, 2, 1286.

Newman, C. G. H., O'Neill, P., and Parker, A. (1967). British Medical fournal, 2, 277.

O'Doherty, N. (1968). In Urinary Tract Infection, edited by F. O'Grady and W. Brumfitt, p. 113. London, Oxford University Press.

Ogg, C. S., Cameron, J. S., and White, R. H. R. (1968). Lancet, 2, 78.

Scherstén, B., and Fritz, H. (1967). Fournal of the American Medical Association, 201, 949 .

Scherstén, B. Dahlqvist, A., Fritz, H., Köhler, L., and Westlund, L. (1968). Fournal of the American Medical Association, 204, 205.

Smellie, J. M., and Normand, I. C. S. (1968). In Urinary Tract Infection, edited by F. O'Grady and W. Brumfitt, p. 123. London, Oxford University Press. 